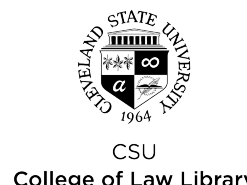

Cleveland State University

College of Law Library

\title{
EngagedScholarship@CSU
}

1978

\section{The Comparative Lawyer and the Middle East}

David F. Forte

Cleveland State University, d.forte@csuohio.edu

Follow this and additional works at: https://engagedscholarship.csuohio.edu/fac_articles

How does access to this work benefit you? Let us know!

\section{Original Citation}

David F. Forte, The Comparative Lawyer and the Middle East, 26 American Journal of Comparative Law 305 (1978)

This Article is brought to you for free and open access by the Faculty Scholarship at EngagedScholarship@CSU. It has been accepted for inclusion in Law Faculty Articles and Essays by an authorized administrator of EngagedScholarship@CSU. For more information, please contact research.services@law.csuohio.edu. 


\section{HEINONLINE}

Citation: 26 Am. J. Comp. L. 305 1977-1978

Content downloaded/printed from

HeinOnline (http://heinonline.org)

Fri Mar 16 14:51:39 2012

-- Your use of this HeinOnline PDF indicates your acceptance of HeinOnline's Terms and Conditions of the license agreement available at http://heinonline.org/HOL/License

-- The search text of this PDF is generated from uncorrected OCR text.

-- To obtain permission to use this article beyond the scope of your HeinOnline license, please use:

https://www.copyright.com/ccc/basicSearch.do?

\&operation $=$ go\&search Type $=0$

\&lastSearch $=$ simple\&all=on\&titleOrStdNo=0002-919X 


\title{
THE COMPARATIVE LAWYER AND THE MIDDLE EAST
}

\author{
by David F. Forte
}

If there be any criticism of Professor Hill's study, it is that it attempts an encyclopedic treatment within the confines of an article. The effort is prodigious, and its very breadth leaves gaps and questions still to be treated. An unfortunate result is that much of the force of the argument is thereby lost.

A thorough review of Professor Hill's article would take as many pages as the original piece. Consequently, I shall make but a few brief comments on the major theme of her essay, namely, how the comparativist should approach the study of Middle Eastern law.

Professor Hill urges a comprehensive and dynamic view of the state of law in the Middle East. She suggests that the law cannot be understood merely as the sum total of its foreign or domestic components, but that it must be seen as a living law, or, in her felicitous phrase, a "law in a condition of becoming." She suggests that only by understanding the interplay between Islamic law, European civil codes, and modern statutes can the mosaic of Middle Eastern law be perceived as an intelligible pattern.

Professor Hill particularly emphasizes the manner in which external law is filtered through linguistic patterns, the jurisprudence of local scholars, and the customs of the people. Codified law may not be a restatement of actual law. She demonstrates how taking a composite view of the law can yield more meaningful conclusions regarding its nature than taking a narrow view can. Yet, at the same time, she discounts the application of this approach to Middle Eastern law. Professor Hill notes that many of the fundamental jurisprudential principles of Western and Near Eastern cultures are so different that there can be no synthesis of their laws. This was particularly true of the period in which parallel jurisdictions were maintained. Contradictory legal values continue to coexist in many Middle Eastern states today.

The overlaying of legal systems in the Middle East has created tension between the old and the new, and full acceptance of modern law has yet to be realized. Eclecticism is a stronger legal tradition in the Middle East than in any other area of the world, including sub-Saharan Africa. Furthermore, there seems to be no Islamic "common law" to fill in the gaps found in the modern codes. Taken as a whole, Professor Hill's essay leaves one with the impression that Middle Eastern law is in a state of contradiction and flux.

In view of this problem, Professor Hill's call for a multidisciplinary approach to comparative law is sound. Nevertheless, it must be recog- 
nized that comparative law has already utilized a multidisciplinary approach, at least in the study of areas outside of the Middle East. Integrating the viewpoints of various disciplines is a practice commonly employed by writers of comparative legal literature: One scholar has recently reminded us that ever since Montesquieu, legal scholars have been acutely aware of the multiplicity of factors which may influence the development of a country's legal institutions. The futility in attempting to impose foreign legal institutions upon an unreceptive nation has long been perceived. ${ }^{1}$ To be sure, comparative law studies in this century have not necessarily been cosmopolitan. A few decades ago, most comparative legal research was simply of a "taxonomic" nature. ${ }^{2}$ Comparative legal study consisted principally of the "pigeonholing" of legal systems into clearly differentiated traditions. It was soon perceived, however, that this method was fundamentally unsatisfactory. A sense of what the actual law was like in its operation was needed. This ushered in a period in which substantive areas of law were compared systematically. ${ }^{3}$ Most comparative legal research is now done in this manner.

Comparative legal study is now beginning to go beyond mere formal analyses of legal systems. It is beginning to analyze law in a "dynamic" fashion by studying the reception and export of legal principles, the effect of political and economic forces on the law, the impact of law on social institutions, and the creation of the law through judicial decisions, legislation, and executive actions. This type of legal study seeks to discern what law is authoritative within a society. For example, is Israeli law truly in a period of "de-Anglicization?" Are Westerneducated judges in Israel still applying common law principles to legal problems?

What is the status of the comparative study of Middle Eastern law? In the last century, when the historical school of jurisprudence was seeking to justify a "pure" nationalistic legal system, Ignaz Goldziher concluded that Islamic law was a combination of traditional norms and values borrowed from ancient legal systems. ${ }^{4}$ Frederick Walton's 1920 study of Egyptian substantive law was done in a comprehensive and systematic manner. ${ }^{5}$ Contemporary research in Islamic law is of an interdisciplinary, "dynamic" nature. ${ }^{6}$

1. Kahn-Freud, "On the Uses and Misuses of Comparative Law," 3 Mod. L. Rev. 1, 6-8 (1974).

2. Kozolchyk, "Trends in Comparative Legal Research: Apropos Dainow's The Role of Judicial Decisions and Doctrine in Civil Law and in Mixed Jurisdictions," 24 Am. J. Comp. L. 100, 109 (1976).

3. Kozolchyk calls this the "normative" stage and describes it somewhat differently. Id. at 110.

4. Id. at 110 n. 36.

5. Walton, The Egyptian Law of Obligations: A Comparative Study with Special Reference to the French and the English Law. (1920).

6. Schacht, Origins of Muhammadan Jurisprudence (1950), Schacht, An In- 
Present-day comparative studies of Middle Eastern law cover a broad range of subjects, including marriage law, ${ }^{7}$ contracts, ${ }^{8}$ and commercial law. ${ }^{9}$ Comparative legal scholars have made exhaustive studies of the interaction of and the conflicts between traditional and modern sources of Middle Eastern law. ${ }^{10}$

In short, Professor Hill's call for an interdisciplinary approach to the study of Middle Eastern law is well taken. The study of legal systems must be done in a comprehensive manner and must take into account the interaction between a country's traditional and received law. Studies of this type however are already being written. The greatest obstacle to the undertaking of further comparative studies is the unavailability until recently of source materials written in languages other than Arabic. (Unfortunately, Arabic is not read by most comparativists). Nonetheless, the increasing availability of translated sources is rapidly eliminating this obstacle.

When one surveys the field of study at the present time, one cannot deny that the comparative studies of Middle Eastern law which have already been done are of unquestioned worth. They possess the same level of analytical sophistication as is demonstrated in the study of other legal systems. This leads one to the conclusion that whatever value there is in Professor Hill's thesis, she is preaching to the converted.

troduction to Islamic Law (1964), Coulson, A History of Islamic Law (1964), Coulson, Conflict and Tensions in Islamic Jurispmudence (1969).

7. Atallah, "L'evolution du droit de la famille dans les pays du l'Afrique du Nord," 32 Univ. Toronto Faculty L. Rev. 33 (1974). Zabel, "Hyde v. Hyde, A Comparative Study of the Law of Marriage in the Sudan and Nigeria," 1969 Utah L. Rev. 22 (1969), 1970 Utah L. R. 526 (1970).

8. Kourides, "The Influence of Islamic Law on Contemporary Middle Eastern Legal Systems: The Formation and Binding Force of Contracts," 9 Colum. J. Transnat'l L. 384 (1970).

9. Fox, "Comparative Commercial Code Legislation of the Republic of Lebanon, West Germany, and the United States," 7 Lex et Scientia 74 (1970).

10. Liebesny, "Comparative Legal History: Its Role in the Analysis of Islamic and Modern Near Eastern Legal Institutions," $20 \mathrm{Am}$. J. Comp. L. 38 (1972); Kourides, "Traditionalism and Modernism in Islamic Law: A Review," 11 Colum. J. Transnat'l L. 491 (1972); Singer, "Islamic Law and the Development of the Ethiopian Legal System," 17 How. L. J. 130 (1971); Anderson, "Modern Trends in Islam: Legal Reform and Modernisation in the Middle East," 20 Int'l \& Comp. L. Q. 1 (1971), and Law Reform in the Muslim World (1976). 
